Jurnal Indonesia Sosial Teknologi: p-ISSN: 2723 - 6609

e-ISSN : 2745-5254

Vol. 2, No. 2 Februari 2021

\title{
ANALISIS FAKTOR-FAKTOR YANG MENDORONG NASABAH BRAND SWITCHING BANK KONVENSIONAL KE BANK SYARIAH MANDIRI KENDARI
}

\section{Muhammad Rizaldi Makmur, Zulfita, La Ode Alimusa dan Endro Sukotjo}

Program Studi Manajemen Fakultas Ekonomi dan Bisnis Islam, Universitas Muhammadiyah Kendari, Sulawesi Tenggara, Indonesia.

Email: rizaldimakmur@gmail.com, zulfitawulandari@gmail.com, alimusa@umkendari.ac.id, endrosukoco@gmail.com

\begin{abstract}
The rapid development of sharia banking system is the impact of the formulation of Law No. 21 of 2008 on Sharia Banking issued on July 16, 2008. Although the Islamic banking industry is in a rapid development stage, it is undeniable that the Islamic banking industry has not achieved the greatest success in all aspects. This study aims to analyze the determining factors of the transfer of Bank customers from Conventional Bank to Bank Syariah Mandiri Kendari. In this study, data collection techniques were conducted using questionnaire methods, interviews, and documentation. While the sampling technique uses accidental sampling method. This study was conducted in Kendari City with 70 respondents. The analysis method used is Exploratory Factor Analysis (EFA). The data is processed using reliability tests, validity and factor analysis. Based on the results of the research shows that what encourages customers to do Conventional Bank Brand Switching to Bank Mandiri Syariah is Factor (1) Economical \&Idiological. Factors (2) Stimulus Marketing (Accessibility, Service Quality, Reference Group, Promotions, Products). The most influential factors are cost factors (economical) and ideological (Islamic Sharia). Cost factor is the most important factor that influences the transfer of customer brand from Conventional Bank to Sharia Bank.
\end{abstract}

Keywords: factor analysis; brand switching; conventional banks; shariah banks.

\section{Abstrak}

Pesatnya perkembangan sistem perbankan syariah merupakan dampak dari rumusan Undang-Undang Nomor 21 tahun 2008 tentang Perbankan Syariah yang diterbitkan pada tanggal 16 Juli 2008. Meski industri perbankan syariah sedang dalam tahap perkembangan yang pesat, tidak dapat dipungkiri bahwa industri perbankan syariah belum mencapai kesuksesan terbesar di segala aspek. Penelitian ini bertujuan untuk menganalisis tentang faktor-faktor penentu nasabah Bank dari Bank Konvensional ke Bank Syariah Mandiri Kendari. Pada penelitian ini teknik pengumpulan data dilakukan Penelitian dengan menggunakan metode kuesioner, wawancara, dan dokumentasi. Sedangkan teknik pengambilan sampel menggunakan metode accidental sampling. Penelitian ini dilakukan di Kota Kendari dengan responden sebanyak 70 orang. Metode analisis yang digunakan adalah Eksploratory Factor Analysis (EFA). Data diolah menggunakan uji 
reliabilitas, validitas dan analisis faktor. Berdasarkan hasil penelitian menunjukan bahwa yang mendorong nasabah melakukan Brand Switching Bank Konvensional ke Bank Mandiri Syariah adalah Faktor (1) Ekonomis \& Idiologis. Faktor (2) Stimulus Marketing (Aksesibilitas, Kualitas Layanan, Kelompok Referensi, Promosi, Produk). Faktor yang paling berpengaruh adalah faktor biaya (ekonomis) dan ideologis (Syari'at Islam). Faktor biaya merupakan faktor terpenting yang mempengaruhi perpindahan merek pelanggan dari Bank Konvensional ke Bank Syariah.

Kata kunci: analisis faktor; brand switching; bank konvensional; bank syariah.

\section{Pendahuluan}

Perkembangan Bank Syariah di dunia merupakan fenomena yang menyita perhatian banyak pihak akhir-akhir ini.Tidak sedikit kajian dilakukan di berbagai tempat untuk mengetahui bagaimana praktik perbankan syariah yang sesungguhnya. Ekonomi syariah dianggap cukup menjanjikan untuk dijadikan alternatif dari sistem perekonomian internasional mengingat sistem perekonomian internasional yang dianut saat ini mulai terlihat memiliki banyak kelemahan. Bank Syariah di Indonesia sekarang telah ada dalam fase perkembangan yang pesat. Hal ini ditunjukkan oleh berbagai data yang dikeluarkan oleh Bank Indonesia mengenai perbankan Syariah tahun 2016. Angka pertumbuhan Bank Syariah sampai dengan bulan Oktober 2016 mampu tumbuh sebesar $37 \%$ sehingga total assetnya menjadi 174,09 triliun. Pembiayaan telah mencapai Rp 135,58 triliun tumbuh 40,06\% dan penghimpunan dana menjadi $\mathrm{Rp} 134,45$ triliun meningkat $32,06 \%$. Juga fakta-fakta lain seperti jumlah Bank Syariah dan unit usaha Syariah yang bertambah cukup banyak dalam jangka waktu beberapa tahun saja (Rozalinda, 2015) .

Berkembangnya sistem Perbankan Syariah yang semakin pesat ini adalah dampak dari diberlakukannya Undang-Undang No. 21 Tahun 2008 tentang Perbankan Syariah yang terbit tanggal 16 juli 2008. Meskipun sedang dalam fase perkembangan yang pesat, tidak dipungkiri Perbankan Syariah belum dapat memaksimalkan pencapaiannya di segala aspek. Salah satunya dalam hal perolehan Produktivitas. Produktivitas yang dicapai oleh bank-bank umum Syariah di Indonesia masih belum begitu memuaskan. Fakta ini dilihat pada rata-rata Produktivitas Bank Umum Syariah masih tertinggal cukup jauh dari Bank Konvensional. Bank Syariah adalah Bank yang melakukan invenstasi halal, sedangkan Bank Konvensional melakukan inventasi tidak melihat faktor kehalallannya. Bank Syariah melayani nasabah dengan prinsip bagi hasil, jual beli dan sewa, sedangkan Bank Konvensional memakai perangkat bunga (riba). Perbankan Syariah di Sulawesi Tenggara sudah berdiri sejak tahun 2004, yang kemudian terus berkembang dengan semakin meningkatnya minat dari masyarakat Sulawesi Tenggara.. Sedangkan bank yang operasionalnya Single Banking System adalah Bank Muamalat Indonesia (BMI) yang berdiri sejak tahun 2004. Selain lembaga bank terdapat beberapat Baitul Mal Wa Tamwil (BMT) sebagai lembaga keuangan mikro syariah. 
Kota Kendari Bank Syariah Mandiri hadir, tampil dan tumbuh sebagai bank yang mampu memadukan idealisme usaha dengan nilai-nilai rohani, yang melandasi kegiatan operasionalnya. Data menunjukan bahwa terjadinya fenomena masyarakat Kota Kendari yang melakukan keputusan perpindahan merek dari konvensional ke Brand Syariah. Fenomena ini terjadi pula pada Bank Syariah Mandiri Cabang Kendari mengalami kemajuan dari tahun ke tahun,. Berikut ini data perpindahan nasabah Bank Mandiri ke BSM Kendari.

Tabel 1.

Data Nasabah yang melakukan brand switching

\begin{tabular}{cccc}
\hline Jenis Kelamin & $\begin{array}{c}\text { Tahun } \\
\mathbf{2 0 1 5}\end{array}$ & $\begin{array}{c}\text { Tahun } \\
\mathbf{2 0 1 6}\end{array}$ & $\begin{array}{c}\text { Tahun } \\
\mathbf{2 0 1 7}\end{array}$ \\
\hline Perempuan & 66 & 65 & 180 \\
\hline Laki-laki & 39 & 41 & 86 \\
\hline Total & $\mathbf{1 0 5}$ & $\mathbf{1 0 6}$ & $\mathbf{2 6 6}$ \\
\hline
\end{tabular}

Sumber: Bank Syariah Mandiri Cab. Kendari, 2018

Berdasarkan uraian fenomena di atas perpindahan yang dilakukan konsumen sering kali terjadi ketika produk jasa yang ditawarkan tidak mampu memberikan apa yang diharapkan oleh konsumen.

(Zainul Arifin, 2012) dalam bukunya Manajemen Bank Syari'ah, menjelaskan bahwa Bank Islam (Syariah) adalah lembaga keuangan yang usaha pokoknya memberikan pembiayaan dan jasa - jasa lainnya dalam lalu lintas pembayaran serta peredaran uang yang pengoperasiannya disesuaikan dengan prinsip Syariat Islam.

Beragamnya merek dari suatu produk yang beredar pesat di pasaran telah membuat konsumen dihadapkan pada berbagai pilihan merek. Hawkins menjelaskan Brand Switching adalah "hasil dari ketidakpuasan konsumen akan suatu produk yang mengakibatkan konsumen melakukan penghentian pembelian produk pada suatu merk dan menggantinya dengan produk dari merk lain". Berbicara mengenai perpindahan merek (Brand Switching), pastinya ada suatu hal atau faktor yang menyebabkan seorang konsumen melakukan perpindahan merek (Brand Switching), faktor tersebut diantaranya adalah biaya, aksesibilitas, kualitas layanan, syariat islam, kelompok referensi, promosi dan produk (Hawkins \& Mothersbaugh, 2010).

Konsumen akan cenderung membeli suatu produk atas evaluasi harga serta nilai dari produk pembanding sejenis lainnya. Jika harga yang di tawarkan suatu merek terlalu mahal sementara karakteristik yang ditawarkan sama dengan pesainggnya maka hal tersebut dapat menimbulkan perpindahan merek (Kotler, Armstrong, Harker, \& Brennan, 1990).

Menurut (Muttaqin \& Dhewi, 2015) menyatakan bahwa memilih lokasi dekat dengan pelanggan perlu untuk mempertahankan daya saing. Kedekatan lokasi maupun kestrategisan nasabah dalam melakukan transaksi sangatlah penting, terutama dilihat dari mudah jangkauannya bank syariah, bank syariah yang berada di pusat keramaian, 
bank syariah yang berada di dekat perkantoran, saluran ( jumlah kantor cabang) bank syariah yang banyak berpengaruh terhadap keputusan Brand Switching.

Kualiatas layanan dan Brand Switching memiliki hubungan kausal yaitu penampilan pegawai sopan dalam memberikan pelayanan kepada nasabah. mengatakan bahwa persepsi konsumen pada kualitas pelayanan merupakan nilai dari keseluruhan dari keunggulan suatu pelayanan (Juniantara \& Sukawati, 2018). Kualitas pelayanan dapat didefinisikan suatu dari pernyataan tentang sikap, yang hubungannya dari hasil perbandingan dari kinerja dan ekspektasi. Peneliti menemukan bahwa informan beranggapan bahwa menurut pengetahuan mereka, kualitas pelayanan Bank Syariah sama saja baiknya dengan Bank Konvensional. Mereka menganggap bahwa belum ada keunggulan dari segi pelayanan Bank Syariah, selain perbedaan penampilan pegawai saja.Meskipun demikian perbedaan penampilan tersebut menjadi ciri khas tersendiri bagi bank syariah dan nasabah yang beranggapan bahwa penampilan pegawai yang sopan dan ramah dalam memberikan layanan tersebut menyebabkan mereka menabung di Bank Syariah.

(HASIL, n.d. 2008) menyatakan bahwa variabel religiuisitas merupakan suatu kepercayaan yang berhubungan dengan hubungan antara manusia dengan penciptanya. Kepercayaan ini akan mendasari manusia dalam mengambil keputusannya. Lembaga keuangan syariah dipandang cocok bagi nasabah terutama yang beragama Islam untuk mengambil pembiayaan karena dalam syariah tidak dikenal riba. Jika seorang merasa bahwa dengan mengambil pembiayaan di kospin jasa layanan syariah sama saja dengan menjalankan perintah atau ajaran agamanya maka nasabah akan melakukan keputusan mengambil pembiayaan.

Kelompok Referensi merupakan standar perbandingan untuk menilai diri penilaian diri dan konsep diri sehingga mampu memunculkan keputusan untuk membeli suatu produk. Kelompok referensi mampu mempengaruhi nasabah melakukan perpindahan merek antara lain yaitu teman, keluarga, kelompok persahabatan, kelompok belanja, kelompok kerja, kelompok atau masyarakat maya dan selebriti (Mantansari, Intan, \& Ika, 2013).

Menurut (Yudhiartika \& Haryanto, 2012), promosi penjualan (sales promotion) adalah suatu cara untuk mempengaruhi konsumen agar dengan suka langsung membeli barang dengan merek tertentu, sehingga dengan adanya sales promotion yang baik akan mudah mempengaruhi konsumen dalam berpindah merek.

Produk merupakan segala sesuatu yang ditawarkan kepada nasabah dengan tujuan untuk memuaskan suatu keinginan nasabah. Produk-produk Bank Syariah yang beragam dan menarik yang tidak kalah saing dengan bank konvensional pada umumnya menjadi daya tarik tersendiri bagi nasabah.

Bentuk simpanan tabungan mudharabah, nama tabungan dengan istilah islam, simpanan yang dapat diambil sewaktu-waktu, jaminan keamanan dan porsi bagi hasil yang ditawarkan Bank Syariah berpengaruh terhadap keputusan nasabah melakukan Brand Switching Ke Bank Syariah. 
Dari latar belakang diatas dapat dijelaskan bahwa tujuan penelitian ini adalah menganalisis tentang faktor-faktor penentu perpindahan nasabah Bank Konvensional ke Bank Syariah Mandiri Kendari. Diharpakan hasil peneltian ini dapat memberikan gamabaran mengenai apa saja faktor-faktor yang mempengaruhi keputusan nasabah melakukan Brand Switching.

\section{Metode Penelitian}

Pada penelitian ini yang menjadi obyek lokasi penelitian yaitu Bank Syariah Mandiri Kota Kendari. Objek penelitian adalah Nasabah yang Berpindah dari Bank Konvensional ke Bank Syariah Mandiri. dengan subyek penelitian adalah nasabah Bank Syariah Mandiri Kendari. Dari keseluruhan populasi yang jumlahnya tidak diketahui dengan pasti, maka sesuai dengan ukuran sampel yang dikemukakan oleh maka sesuai dengan jumlah indikator variabel yaitu sebanyak. Dengan demikian jumlah sampel dalam penelitian ini adalah sebanyak $10 \times 7$ variabel $=70$ orang sampel. Teknik pengambilan sampel yang digunakan adalah accidental sampling. Adapun metode analisis data yang digunakan dalam penelitian ini adalah analisis faktor. Penelitian ini merupakan penelitian Eksploratory Factor Analysis (EFA).

\section{Hasil dan Pembahasan}

a. Hasil Uji KMO, Bartlett Test Of Sphericity, dan Uji MSA

Dari hasil pengelolaan data dengan SPSS dapat ditampilkan tabel KMO dan Bartlett's Measure Of Sampling Adequancy (MSA).

\section{Tabel 2.}

KMO and Bartlett's Test

\begin{tabular}{llr}
\hline $\begin{array}{l}\text { Kaiser-Meyer-Olkin Measure of Sampling } \\
\text { Adequacy. }\end{array}$ & .722 \\
\hline $\begin{array}{llr}\text { Bartlett's Test of } \\
\text { Sphericity }\end{array}$ & Approx. Chi-Square & 132.189 \\
\cline { 2 - 3 } & Df & .000 \\
\cline { 2 - 3 }
\end{tabular}

Berdasarkan tabel 2 diatas dapat dilihat bahwa angka KMO adalah 0,722 dengan signifikansi 0,000 yang berarti variabel telah memenuhi syarat untuk dilakukan uji MSA.

Berikut ini adalah tabel dari nilai hasil uji MSA:

Tabel 3.

Anti-image Matrices

\begin{tabular}{|c|c|c|c|c|c|c|c|c|}
\hline & & Biaya & Aksesibilitas & $\begin{array}{l}\text { kualitas } \\
\text { layanan }\end{array}$ & $\begin{array}{l}\text { syariat } \\
\text { islam }\end{array}$ & $\begin{array}{c}\text { kelompok } \\
\text { referensi }\end{array}$ & Promosi & Produk \\
\hline \multirow{2}{*}{$\begin{array}{l}\text { Anti-image } \\
\text { Covariance }\end{array}$} & Biaya & .390 & -.087 & -.099 & -.273 & .060 & .029 & -.116 \\
\hline & Aksesibilitas & -.087 & .702 & .055 & -.031 & -.082 & -.239 & -.052 \\
\hline
\end{tabular}


Analisis Faktor-Faktor yang Mendorong Nasabah Brand Switching Bank Konvensional Ke Bank Syariah

\begin{tabular}{|c|c|c|c|c|c|c|c|c|}
\hline & $\begin{array}{l}\text { kualitas } \\
\text { layanan }\end{array}$ & -.099 & .055 & .674 & -.045 & -.127 & -.203 & -.063 \\
\hline & syariat islam & -.273 & -.031 & -.045 & .457 & -.003 & .012 & .011 \\
\hline & $\begin{array}{l}\text { kelompok } \\
\text { referensi }\end{array}$ & .060 & -.082 & -.127 & -.003 & .901 & .090 & -.169 \\
\hline & Promosi & .029 & -.239 & -.203 & .012 & .090 & .636 & -.172 \\
\hline & Produk & -.116 & -.052 & -.063 & .011 & -.169 & -.172 & .655 \\
\hline \multirow{7}{*}{$\begin{array}{l}\text { Anti-image } \\
\text { Correlation }\end{array}$} & Biaya & $.673^{a}$ & -.167 & -.193 & -.648 & .101 & .059 & -.229 \\
\hline & Aksesibilitas & -.167 & $.783^{\mathrm{a}}$ & .079 & -.055 & -.103 & -.357 & -.076 \\
\hline & $\begin{array}{l}\text { kualitas } \\
\text { layanan }\end{array}$ & -.193 & .079 & $.804^{\mathrm{a}}$ & -.081 & -.164 & -.311 & -.094 \\
\hline & syariat islam & -.648 & -.055 & -.081 & $.682^{\mathrm{a}}$ & -.005 & .023 & .020 \\
\hline & $\begin{array}{l}\text { kelompok } \\
\text { referensi }\end{array}$ & .101 & -.103 & -.164 & -.005 & $.530^{\mathrm{a}}$ & .120 & -.220 \\
\hline & Promosi & .059 & -.357 & -.311 & .023 & .120 & $.690^{\mathrm{a}}$ & -.267 \\
\hline & Produk & -.229 & -.076 & -.094 & .020 & -.220 & -.267 & $.811^{\mathrm{a}}$ \\
\hline
\end{tabular}

a. Measures of Sampling Adequacy(MSA)

\section{Sumber: Hasil Output SPSS}

Dari tabel 3 diatas diketahui bahwa variabel-variabel dalam penelitian ini memilki nilai MSA > 0.5 sehingga variabel dapat dianalisis secara keseluruhan lebih lanjut.

\section{b. Hasil Factoring dan Rotasi}

Setelah semua variabel memiliki nilai yang mencukupi, tahap selanjutnya adalah melakukan ekstraksi terhadap sekumpulan variabel yang sudah ada, sehingga terbentuk satu atau beberapa faktor. Dalam melakukan proses ekstraksi ini metode yang digunakan adalah Principal Component Analysis.

Berikut adalah tabel Communalities dari 7 variabel yang telah melalui proses factoring :

Tabel 4.

Communalities

\begin{tabular}{lcc}
\hline & Initial & Extraction \\
\hline Biaya & 1.000 & .817 \\
\hline Aksesibilitas & 1.000 & .431 \\
\hline Kualitas Layanan & 1.000 & .479 \\
\hline Syariat Islam & 1.000 & .776 \\
\hline Kelompok Referensi & 1.000 & .511 \\
\hline Promosi & 1.000 & .507 \\
\hline Produk & 1.000 & .567
\end{tabular}

Extraction Method: Principal Component Analysis.

Sumber: Hasil Output SPSS 
Singgih Santoso menjelaskan bahwa tabel total Variance Explainedmenggambarkan jumlah faktor yang terbentuk.Dalam melihat faktor yang terbentuk, maka dapat dilihat pada nilai eigenvaluesnya harus berada diatas angka satu (1), jika sudah berada di bawah angka satu maka sudah tidak tepat.Eigenvalues menunjukkan kepentingan relativ masing-masing faktor dalam menghitung varians dari total variabel yang ada. Jumlah angka eigenvalues, susunannya selalu diurutkan pada nilai terbesar samapai yang terkecil (Santoso, 2016).

Tabel 5.

Total Variance Explained

\begin{tabular}{|c|c|c|c|c|c|c|}
\hline \multirow[t]{2}{*}{ Component } & \multicolumn{3}{|c|}{ Initial Eigenvalues } & \multicolumn{3}{|c|}{ Extraction Sums of Squared } \\
\hline & Total & $\begin{array}{c}\% \text { of } \\
\text { Variance }\end{array}$ & $\begin{array}{c}\text { Cumulative } \\
\%\end{array}$ & Total & $\begin{array}{c}\% \text { of } \\
\text { Variance }\end{array}$ & $\begin{array}{c}\text { Cumulative } \\
\%\end{array}$ \\
\hline 1 & 2.974 & 42.492 & 42.492 & 2.974 & 42.492 & 42.492 \\
\hline 2 & 1.113 & 15.896 & 58.388 & 1.113 & 15.896 & 58.388 \\
\hline 3 & .942 & 13.451 & 71.839 & & & \\
\hline 4 & .732 & 10.460 & 82.299 & & & \\
\hline 5 & .586 & 8.374 & 90.672 & & & \\
\hline 6 & .405 & 5.788 & 96.460 & & & \\
\hline 7 & .248 & 3.540 & 100.000 & & & \\
\hline
\end{tabular}

Extraction Method: Principal Component Analysis.

Setelah diketahui bahwa 2 faktor adalah jumlah yang paling optimal, tabel Component Metrix menujukkan distribusi ketujuh variabel tersebut pada dua faktor yang terbentuk.

Sedangkan angka-angka yang ada pada tabel tersebut adalah factoring loadings, yang menunjukkan besar korelasi antara suatu variabel faktor 1 atau faktor 2. Proses penentuan variabel mana yang akan masuk kefaktor yang mana ditentukan dengan melakukan perbandingan besar korelasi pada setiap baris.

Tabel 6.

\begin{tabular}{lcc}
\hline \multicolumn{3}{c}{ Rotated Component Matrix $^{\mathbf{a}}$} \\
\hline \multicolumn{3}{c}{ Component $^{-}$} \\
\hline Biaya & 1 & 2 \\
\hline Syariat Islam & .875 & .224 \\
\hline Produk & .873 & .117 \\
\hline Promosi & .323 & .680 \\
\hline
\end{tabular}




\begin{tabular}{|c|c|c|}
\hline Kelompok Referensi & -.278 & .658 \\
\hline Kualitas Layanan & .417 & .552 \\
\hline Aksesibilitas & .361 & .548 \\
\hline \multicolumn{3}{|c|}{$\begin{array}{l}\text { Extraction Method: Principal Component Analysis. } \\
\text { Rotation Method: Varimax with Kaiser Normalization. }\end{array}$} \\
\hline
\end{tabular}

Berdasarkan tabel diatas mennjukkan bahwa faktor yang terbentuk ada 2 faktor:

Faktor 1: Variabel Biaya $(0,875)$, dan variabel Syariat Islam $(0,873)$.

Faktor 2: Variabel produk $(0,680)$, variabel Promosi (0,667), variabel Kelompok Referensi $(0,658)$, variabel Kualitas Layanan $(0,552)$, dan variabell Aksesibilitas (0,548).

Tabel 7.

\begin{tabular}{lcc}
\hline \multicolumn{3}{c}{ Component Transformation Matrix } \\
\hline Component & 1 & 2 \\
\hline 1 & .720 & .694 \\
\hline 2 & -.694 & .720 \\
\hline
\end{tabular}

Extraction Method: Principal Component Analysis.

Rotation Method: Varimax with Kaiser Normalization.

Sumber: Hasil Output SPSS

Pada tabel 7 Component Transformation Matrixdiatas dapat diamati angkaangka yang berada pada diagonal, antara komponen 1 dengan 1 dan antara komponen 2 dengan 2.

Terlihat kedua angka jauh diatas 0,5 (0,720 dan 0,720). Hal ini membuktikan kedua factor (component) yang terbentuk sudah tepat, karena mempunyai korelasi yang tinggi.

Hasil dari penelitian ini dapat diketahui bahwa terdapat dua faktor terbentuk yang mendorong nasabah dalam melakukan Brand Switching Bank Konvensional Ke Bank Syariah Mandiri Kendari. Faktor 1 (pertama) adalah faktor biaya dan syariat islam yang mempengaruhi nasabah dalam melakukan Brand Switching. Hasil analisis menunjukan faktor ekonomis (biaya) \& faktor idiologis (Syariat Islam) merupakan faktor paling dominan yang dipertimbangkan nasabah dalam melakukan Brand Switching dari Bank Konvensional ke Bank Syariah Mandiri Kendari. Faktor biaya menjadi faktor utama bagi nasabah dalam melakukan Brand Switching. Dimana biaya administrasi yang murah, saldo minimum tabungan terjangkau, dan kesesuaian harga produk dengan manfaat menjadi pertimbagan penting bagi nasabah dalam melakukan 
Brand Switching Bank Konvensional Ke Bank Syariah Mandiri Kendari. Hal ini dapat dijelaskan bahwa biaya menjadi karakteristik pokok bagi bank syariah dalam melaksanakan kegiatan operasinya. Kemudian faktor idiologis (Syariat Islam) menjadi faktor pertimbangan kedua bagi nasabah dalam melakukan Brand Switching. Artinya pemahaman nasabah tentang Syariat islam tidak dijadikan pertimbangan utama nasabah dalam melakukan Brand Switching Bank Konvensional Ke Bank Syariah Mandiri Kendari.

Faktor ekonomis (biaya) \& faktor idiologis (syariat islam) memiliki perpaduan/hubungan yang kuat dalam mempengaruhi nasabah melakukan Brand Switching Bank Konvensional Ke Bank Syariah Mandiri Kendari. Dimana biaya dan saldo minimum tabungan di Bank Syariah mudah di jangkau oleh nasabah, akad \& tijarah (jual beli) yang ditawarkan bank syariah juga jelas unsur kehalallannya, sehingga mempengaruhi nasabah dalam melakukan Brand Switching Bank Konvensional Ke Bank Syariah Mandiri Kendari.

Penelitian yang dilakukan oleh (Sulistyo, 2016). "Analisis Pengaruh Iklan, Harga, dan Ketidakpuasan Terhadap Perpindahan Merek Sabun Mandi," menunjukan bahwa harga berpengaruh signifikan terhadap perpindahan merek. Berdasarkan pernyataan tersebut, harga dapat mempengaruhi konsumen untuk menggunakan produk tersebut. Kecenderungan penelitian terdahulu menunjukan bahwa faktor agama bukan menjadi pertimbangan utama bagi nasabah dalam memilih produk bank syariah diantaranya adalah hasil penelitian (Hasan, Subhani, \& Osman, 2012) menemukan bahwa motif agama adalah faktor kedua bagi nasabah dalam memilih bank syariah setelah faktor ekonomi (highprofit \& low service chargers) (Hasan et al., 2012).

(Najib, 2009) “Analisis Konsumen Berpindah Merek (Brand Switching) Pada Bank Syariah dan Bank Konvensional". Hasil penelitian menunjukan faktor yang memiliki pengaruh paling tinggi terhadap konsumen dalam melakukan perpindahan merek adalah faktor internal dan diikuti oleh faktor eksternal, dimana faktor internal yang dimaksud disini adalah biaya, seperti biaya administrasi yang murah, saldo minimum tabungan terjangkau, dan kesesuaian harga produk dengan manfaat. Faktor eksternal yang dimaksud yaitu syariat islam, seperti akad dan tijarah yang jelas, serta adanya unsur kehalallan pada setiap produk Bank Syariah.

Faktor ke 2 (dua) adalah faktor stimulus marketing yang terdiri dari produk, promosi, aksesibilitas, kualitas layanan, dan kelompok referensi yang mempengaruhi keputusan perpindahan merek (Brand Switching) Bank Konvensional ke Bank Syariah Mandiri Kendari. Faktor yang paling utama dalam penelitian ini adalah faktor ekonomis (Kotler \& Armstrong, 2010), seorang konsumen akan cenderung membeli suatu produk atas evaluasi harga serta nilai dari produk pembanding sejenis lainnya. Jika harga yang ditawarkan suatu merek terlalu mahal sementara karakteristik yang ditawarkan sama dengan pesaingnya maka hal tersebut dapat menimbulkan perpindahan merek. 


\section{Kesimpulan}

Berdasarkan hasil penelitian dan pembahasan yang yang telah diuraikan pada BAB sebelumnya mengenai Analisis Faktor-Faktor Yang Mendorong Nasabah Brand Switching Bank Konvensional ke Bank Syariah Mandiri Kendari maka dapat disimpulkan bahwa: 1) Terdapat dua faktor terbentuk yang mendorong nasabah melakukan Brand Switching Bank Konvensional ke Bank Mandiri Syariah yaitu Faktor (1) Ekonomis \& Idiologis. Faktor (2) Stimulus Marketing (Produk, Promosi, Kelompok Referensi, Kualitas Layanan, dan Aksesibilitas). 2) Faktor yang paling besar pengaruhnya bagi nasabah dalam melakukan Brand Switching dari Bank Konvensional ke Bank Syariah Mandiri yaitu faktor ekonomis (biaya) \& idiologis (syariat islam). Faktor biaya menjadi faktor paling utama yang berpengaruh bagi nasabah dalam melakukan Brand Switching. 


\section{Bibliografi}

Hasan, Syed Akif, Subhani, Muhammad Imtiaz, \& Osman, Ms. (2012). Consumer criteria for the selection of an Islamic Bank: Evidence from Pakistan.

HASIL, BUNGA BAGI. (N.D.). FAKTOR-FAKTOR YANG MEMPENGARUHI PERMINTAAN PEMBIAYAAN KREDIT PADA PT. BANK BRI SYARIAH PEKANBARU Eriyati.

Hawkins, Del I., \& Mothersbaugh, David L. (2010). Consumer behavior: Building marketing strategy. Boston: McGraw-Hill Irwin,.

Juniantara, I. Made Adi, \& Sukawati, Tjokorda Gde Raka. (2018). Pengaruh Persepsi Harga, Promosi, Dan Kualitas Pelayanan Terhadap Kepuasan Dan Dampaknya Terhadap Loyalitas Konsumen. E-Jurnal Manajemen, 7(11), 5955-5982.

Kotler, Philip, \& Armstrong, Gary. (2010). Principles of marketing. Pearson education.

Kotler, Philip, Armstrong, Gary, Harker, Michael, \& Brennan, Ross. (1990). Marketing: an introduction (Vol. 1). Prentice-Hall Englewood Cliffs, NJ.

Mantansari, Alens Diana, Intan, R., \& Ika, A. S. (2013). Perilaku Brand Switching (Perubahan Merek) pada Telepon Seluler yang Dipengaruhi oleh Reference Group (Kelompok Acuan)(Studi pada Mahasiswa Psikologi Universitas Brawijaya Malang). Universitas Brawijaya Malang.

Muttaqin, Indra, \& Dhewi, Titis Shinta. (2015). Pengaruh Fasilitas dan Lokasi Terhadap Keputusan Menginap. Ekonomi Bisnis, 20(1), 88-91.

Najib, Mukhamad. (2009). Analisis konsumen berpindah merek (BrandSwitcher) pada bank syariah dan bank konvensional (studi kasus pada nasabah Di wilayah darmaga bogor). Tazkia Islamic Finance and Business Review, 4(1).

Rozalinda, Rozalinda. (2015). Epistemologi Ekonomi Islam dan Pengembangannya pada Kurikulum Ekonomi Islam di Perguruan Tinggi. HUMAN FALAH: Jurnal Ekonomi Dan Bisnis Islam, 2(1), 1-28.

Santoso, Singgih. (2016). Panduan Lengkap SPSS Versi 23. Elex Media Komputindo.

Sulistyo, Budhi Ade. (2016). Analisis Pengaruh Perpindahan Merek melalui Harga, Iklan dan Ketidakpuasan Konsumen. Management Analysis Journal, 5(2).

Yudhiartika, Dian, \& Haryanto, Jony Oktavian. (2012). Pengaruh Personal Selling, Display, Promosi Penjualan Terhadap Kesadaran Merek Dan Intensi Membeli Pada Produk Kecantikan Pond's. Buletin Studi Ekonomi.

Zainul Arifin, M. B. A. (2012). Dasar-dasar manajemen bank syariah. Pustaka Alvabet. 